\title{
A CULPA DO CHEFE ATRIDA: UMA ABORDAGEM NO AGAMÉMNONDE SÉNECA
}

\author{
* Membro \\ Alexandra Coelho dos Santos* \\ colaborador \\ do Centro de \\ Estudos Clássicos \\ e Humanísticos, \\ Universidade de \\ Coimbra.
}

RESUMO: Pretende este artigo centrar-se em alguns aspetos que envolvem a figura de Agamémnon na tragédia homónima de Séneca, tanto no plano temático como no plano simbólico, abarcando a questão da dimensão hereditária do crime, a morte de Ifigénia e a ligação do chefe Atrida a Cassandra, elementos que despoletam o furor de Clitemnestra e que culminará com a morte de Agamémnon no banquete ímpio. Não podendo dissociar esta tragédia da filosofia estoica, será objeto de reflexão a ação das personagens na sua busca dos valores do sapiens estoico.

PALAVRAS-CHAVE: Tragédia; Séneca; Agamémnon; culpa; filosofia estoica.

\section{THE GUILT OF LEADER ATRIDES: AN APPROACH TO SENECA'S AGAMEMNON}

\begin{abstract}
The present paper focus on aspects of the Agamemnon persona, in the Senecan homonym tragedy, thematically and in symbolic terms. It covers the question of crime's hereditary dimension, Iphigenia's death and Atrides and Cassandra's connection. These elements trigger Clytemnestra's furor that will culminate with the death of Agamemnon at the impious banquet. Because stoic tragedy cannot be dissociated, personae's action will be studied in their quest of stoic sapiens values.
\end{abstract}

KEYWORDS: Tragedy; Seneca; Agamemnon; guilty; stoic philosophy. 


\section{A TRAgÉdia DE SÉNECA}

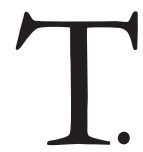

P. Wiseman escreve: “Uma coisa é certa: Roma já conhecia o drama antes de Lívio Andronico introduzir peças gregas em latim”. A verdade é que, ao um género com grande tradição em Roma.

O povo romano demorou a tomar consciência de que o teatro era uma "atitude civilizada", mas passada esta resistência ao género, a quantidade de teatros construídos no mundo romano faz elevar a sua importância no ambiente cultural da época. ${ }^{2}$

Poucos são os nomes encontrados na esteira da tragédia latina: Énio, Pacúvio e Ácio são os tragediógrafos mais antigos; Vário e Ovídio, surgem no período clássico, seguindose Séneca, com o qual a tragédia romana alcançou a sua maturidade. A tragédia latina, ao contrário do que acontecia com a grega, e apesar de nela ter ido beber influência, não coloca em cena a angústia do homem perante o seu destino, mas busca a ênfase, o desenvolvimento excessivo das ações, com situações fora do normal, os artifícios e os lenocínios da forma, as almas monstruosas, a criação de situações patéticas e o espetacular, ${ }^{3}$ elementos que encontraremos em Séneca.

Séneca nasce em Córdova, por volta do ano IV a. C., um homem que sob a alçada da fineza e da sinceridade reconhece e analisa os seus defeitos, "sentindo-se por isso impelido a amar, mais a fundo, também, a humanidade no seu conjunto, não obstante o tradicional orgulho do sapiens". ${ }^{4}$

A atividade literária de Séneca inspira-se na máxima primum scribere, deinde philosophari, e a sua oratória era subtil, com uma "fina altivez, com moderna vivacidade e variedade de recordações, com sabedoria de esboços e efeitos imprevistos, com virtuosismo de repetições que facetam uma ideia e a tornam sempre nova, [que nos faz] penetrar no vivo dum pensamento que é sofrimento, que é a consciência atormentada de todas as infinitas contradições da vida e da vida humana". 5 O que se verifica é que tanto nas suas obras filosóficas como nas obras dramáticas persiste a mesma moral estoica, e o mesmo é dizer que os elementos filosóficos perpassam as suas tragédias conferindo-lhes um pendor didático.

Das formas antigas de poesia, a tragédia apresenta-se como aquela que mais se aproxima e conecta com as ideias, com a filosofia, assim como com as teorias poéticas da filosofia. ${ }^{6}$

Enquanto tragediógrafo escreveu nove peças: Herculens furens, Troades, Phoenissae, Medea, Phaedra, Oedipus, Agamemnon, Thyestes, Hercules Oetaeus. Nestas, deparamo-nos com a influência dos grandes trágicos gregos, seja ela no Agamemnon que bebe em Ésquilo, no

\footnotetext{
${ }^{1}$ Wiseman, 1989, p. 137 apud Rocha Pereira, 1989, p. 65.

${ }^{2}$ Wiseman, 1989, p. 137 apud Rocha Pereira, 1989, p. 67-69.

${ }^{3}$ Soares, 1998, p. 40 e Bayet, 1985, p. 324.

${ }^{4}$ Paratore, 1983, p. 577.

${ }^{5}$ Paratore, 1983, p. 577.

${ }^{6}$ Most, 2000 apud Staley, p. 28.
} 
Oedipus, nas Phoenissae e Hercules Oetaeus em Sófocles, e em Eurípides em Hercules furens, Troades, Medea e Phaedra, tendo este último poeta grego exercido a maior influência no latino. Relativamente à tragédia Thyestes não sabemos ao certo qual foi a sua influência, mas provavelmente foi em Vário.

A cronologia das suas obras aparece coberta de dúvidas e não se sabe precisar com exatidão as datas das suas criações. Há quem considere que as tragédias foram escritas de forma contínua, após a sua saída definitiva da corte no ano 62 d.C.; outros, que foram escritas durante um longo período de tempo. A dúvida ainda persiste, mas impera aquela que considera que as suas tragédias foram escritas a seguir à sua retirada da corte, já que muitos veem nelas uma atitude de reivindicação da liberdade contra a tirania de Nero. ${ }^{7}$ Pierre Grimal considera que as suas tragédias são um grito contra a tirania e o mundo do arbítrio, da violência, uma expressão de um ideal prático de vida política, que se apresenta contrária aos do tempo em que vive. ${ }^{8}$ A tragédia torna-se, pois, uma fonte de inspiração para a filosofia estoica, filosofia que tentava demonstrar o quão funesta era a paixão humana e ao que levava esta falta de limites, quando não se moderava essa mesma paixão e não se seguia a lógica. A tragédia senequiana, na medida em que explora a vida humana, leva alguns críticos a pensarem até que ponto o filósofo usa a tragédia como veículo para ensinar a sua filosofia. ${ }^{9}$

Apesar da influência euripidiana e do aproveitamento das temáticas míticas de origem clássica, as tragédias de Séneca apresentam elementos bastantes originais, baseado muitas vezes na filosofia estoica, em que o homem agia não segundo a ratio mas através do sentimento, do adfectus, podendo cair no furor, numa espécie de delírio. ${ }^{10}$ Acarretam as suas obras o dom da palavra que se traduz muitas vezes como um mordaz lógos que atinge o seu auge num horror trágico, onde são feitas análises psicológicas das personagens, onde a moral escreve o seu tónico, visível no discurso proferido pelas personagens e pelo coro que as acompanha, e onde são entretecidos os mitos antigos, que perdem aqui o seu pendor sagrado, tão caro às tragédias gregas, ao serem utilizados de forma alegórica.

Torna-se importante verificar nas suas tragédias, e no que respeita à introdução dos mitos, a presença em forma de exempla desses, na medida em que se encontra o fundamento para o trágico, ou seja, quando a paixão descontrolada se sobrepõe à razão, gera, por conseguinte, esse mesmo acontecimento trágico. Desta forma, demonstra como é que aqueles que se deixam dominar pelas paixões irracionais se distanciam da atitude do homem ideal, o sábio, aquele que seria capaz de manter a racionalização dos sentimentos, assim como dos impulsos e das paixões. Medeia traduz-se como um exemplo de pessoa dominada pelas paixões que se torna enferma, e movida dessa mesma paixão desmedida, não consegue controlar a sua fúria e o desejo de vingança, desencadeando, assim, a catástrofe. ${ }^{11}$ Realça-se

\footnotetext{
${ }^{7}$ Bayet, 1985, p. 598.

${ }^{8}$ Grimal, 1992 apud Soares, 1998, p. 45.

${ }^{9}$ Graf, 2007, p. 59.

${ }^{10}$ Soares, 1998, p. 44-45.

${ }^{11}$ Pirateli, 2008, p. 260.
} 
ainda o facto de que os deuses do mito nas tragédias senequianas apresentam-se como uma metáfora do poder que comanda a vida humana.

Mas há que atentar que os mitos para os romanos não tinham o mesmo peso que para os gregos, pois o mito é inerente à cultura grega e faz parte da sua realidade, traduzindo-se como um meio de celebrar a memória coletiva. Para os romanos, o mito aparece como um elemento da composição dramática, de cariz estrangeiro, que serve para conotar o crime cometido como um scelus nefas, um crime com carga simbólica que se apresenta como um ato contra a humanidade e as leis que governam o mundo.

O crime é apresentado em Séneca através da palavra, sendo que "a arte do discurso dramático senequiano impõe-se pela sublimidade e grandeza de estilo, pela mestria das frases sentenciosas e pela facilidade em manusear o léxico latino com uma fina tékhnē retórica, adequada à função emotiva, à plena realização do páthos, que apela às paixões do público, com fins de persuasão". ${ }^{12}$

A palavra era vista, entre os romanos, como um espetáculo teatral e não simplesmente um meio de representação, e como tal, os romanos criaram a palavra de ficção, de criação, e desta forma, na arte dramática latina, “a palavra é um canto criador em que o herói não age sobre os outros, mas sobre ele mesmo e sobre o espaço cénico". ${ }^{13}$

As personagens de Séneca têm como característica um conflito interno marcado pela luta entre a razão e as paixões, e, mesmo que não se apresentem como donas do seu próprio destino, são dotadas de livre-arbítrio, possuindo a consciência de que poderão fazer o bem e repelir o mal. Desta forma, a tragédia que acontece "não está no jogo dos acidentes alheios à vontade em que o homem se pode ver enredado sem qualquer culpa, mas na incapacidade ou na vontade de subordinar todas as suas ações aos ditames da razão". ${ }^{14}$

Se na tragédia grega o fatum é na maioria das vezes responsável pelo final trágico, em Séneca a grande responsabilidade é dos homens, onde a vitória das paixões sobre a razão determina a desgraça, dependendo das opções humanas o que há-de vir. ${ }^{15} \mathrm{O}$ fatum é assim substituído pelo furor, a loucura trágica, e as paixões descontroladas desencadeiam a própria catástrofe. Na tragédia de Séneca, o homem torna-se, pois, responsável pelos seus atos.

Relativamente ao aspeto técnico, as tragédias senequianas procuram a perfeição métrica, obedecendo a um movimento iniciado na época de Augusto e aperfeiçoado no século primeiro do Império. ${ }^{16}$ Relativamente ao aspeto artístico, há quem considere que as suas obras tenham sido criadas não para representação mas para leitura, já que se encontra muita retórica nas suas linhas, não conseguindo atingir o clímax trágico, do horror e da compaixão, preconizado por Aristóteles no que respeita ao fim último da tragédia. Sendo o seu drama sentencioso, altamente psicológico e didático, expresso nos longos monólogos e com cenas onde a violência, o sangue, o horror e o terror assumem proporções gigantescas,

\footnotetext{
${ }^{12}$ Soares, 2004, p. 94.

${ }^{13}$ Montagner, 2007, p. 8.

${ }^{14}$ Segurado e Campos, 1996, p. 41 apud Pirateli, 2008, p. 261.

${ }^{15}$ Cardoso, 2005, p. 7.

${ }^{16}$ Paratore, 1983, p. 598.
} 
são apontados como textos que, então, não seriam representados, mas criados para serem divulgados através das recitationes. Tarrant ${ }^{17}$ considera que a peça Agamémnon (focamos esta obra porque será ela fruto da nossa atenção) foi feita para recitação, sobretudo pela dificuldade que seria colocar em cena determinados elementos no palco. No entanto, Florence Dupont ${ }^{18}$ refuta a ideia de que Séneca houvesse composto as tragédias apenas para leitura, referindo que estas obras se prestavam a espetáculos grandiosos.

Para representação ou não, as tragédias de Séneca são a viva imagem dos sentimentos do homem, um exemplum da tragédia da condição humana, e pela sua grandeza deparamonos com a sua influência nos grandes dramas da Renascença.

\section{AGAMÉmNON de SÉnECA: A CULPA do CHEFE ATRIDA}

Mais do que a estrutura da peça ou dos elementos retóricos e estilísticos que a constituem, o que nos interessa neste trabalho é centrar em alguns aspetos que circundam a figura de Agamémnon, e que se prendem sobretudo com a figura do "chefe dos chefes", que fruto de uma carga hereditária sofrerá uma morte trágica num banquete ímpio. Não nos esqueceremos, contudo, de traçar algumas considerações sobre a filosofia estoica nas ações e atitudes das personagens, já que esta está sempre presente na escrita de Séneca.

Séneca, nas suas tragédias, aborda o trágico de maneira diferente das obras gregas, apesar de nelas se inspirar. No Agamémnon, ao contrário do que acontece com Oedipus e Herculens furens em que se denota um toque grego no que respeita à catástrofe, nesta e nas outras peças encontramos a visão do filósofo estoico, em que o furor, a paixão não controlada, é o que desencadeia a catástrofe. ${ }^{19}$

A tragédia de Séneca reflete a sua compreensão relativamente às emoções trágicas, relegando para segundo plano o enredo. O que lhe interessa é como os caracteres se dão com as suas emoções de medo, dor e raiva, e como se relacionam com os seus destinos. Desta forma, os espectadores do teatro romano, sem nunca se renderem às suas verdadeiras emoções, aprendem a reconhecer um impulso físico inicial, ajudando assim a lidar com a dor numa situação na vida real. ${ }^{20}$

Ao contrário das tragédias gregas em que o número de cantos corais era adaptado à estrutura particular de uma peça, nos dramas senequianos encontramos quatro cantos corais divididos numa peça de cinco atos. O primeiro ato está devotado à exposição, normalmente uma exposição emocional, sendo a quantidade de informação transmitida quase insignificante, pois assume-se a ideia de que a audiência já tinha um conhecimento prévio dos detalhes da ação, e surge como se os caracteres conhecessem o seu futuro, tal como conhecem o seu passado. O segundo ato surge com um subalterno a tentar deter o carácter principal a não cometer o crime; no terceiro, dá-se a execução do crime propriamente dito, enquanto

\footnotetext{
${ }^{17}$ Tarrant, 1976, p. 7 apud Erasmo, 2004, p. 136.

${ }^{18}$ Dupont, 1995, p. 9.

${ }^{19}$ Cardoso, 1999, p. 130-131.

${ }^{20}$ Wiles, 2007, p. 100.
} 
que no quarto ato aparece a descrição ou a exibição do crime, finalizando-se com o quinto, onde nos são apresentados as consequências ou efeitos que estes crime trará para o futuro. ${ }^{21}$

A peça Agamémnon não foge a esta estrutura, e surge, assim, dividida em cinco atos, desenvolvendo-se em cenas que parecem estar isoladas umas das outras, mas que acabam por ter, de certa forma, um momento central no ato III (com a narração de Euribates sobre a tempestade), onde nos é relatado o regresso de Agamémnon após a guerra em Troia, dez anos depois, regresso que culminará num trágico desenlace.

A tragédia Agamémnon insere-se na temática das lendas da casa dos Atridas que assentavam na maldição eterna a que esta família havia sido condenada, ${ }^{22}$ devido ao delito endógeno, do scelus praticado na consanguinidade e várias vezes repetido dentro da mesma estirpe e da culpa hereditária, que se verifica ao longo das gerações ${ }^{23}$.

Abre o ato I com o fantasma de Tiestes, e ao colocar no prólogo este espectro, Séneca situa esta história no drama familiar, já que este é irmão de Atreu e tio de Agamémnon. O local de onde vem a Vmbra de Tiestes, da opaca linquens ("estância escura", v. 1), não surge melhor do que o ambiente em que se encontra agora, regressado do mundo dos mortos, e como tal acaba por não saber qual das duas moradas odeia mais (Incertus utras oderim sedes magis, v. 3).

Assim, descrevendo o que se passa na casa de Pélope (v. 7), introduzida pela expressão mos est, acaba por conferir às palavras de Tiestes "uma dimensão retrospectiva e prospectiva no tratamento do tópico do scelus alternum, glosado, em parte, pelo Coro de mulheres de Micenas da ode seguinte (v. 77-79)". ${ }^{24}$ É descrito, pois, o espaço onde mais tarde ocorrerá o crime, e encontramos quase uma transposição do festim de Tântalo para o seu, só que neste caso será Agamémnon a vítima. Segue-se um périplo pelos castigos dos condenados, ilustrados de forma a mostrar a superioridade das suas culpas relativamente a estes, e desta forma reclama-se como um digno herdeiro da tradição familiar criminosa, que culminou com o incesto com a filha. Tiestes apresenta-se como o representante máximo dos monstra, um dos leitmotive das tragédias senequianas. ${ }^{25}$

Já neste ponto, na fala de Tiestes, encontramos uma identificação anti-estoica entre a Fortuna e o destino (v. 29-31), ${ }^{26}$ já que a refeição que Tiestes faz com a carne dos filhos e do incesto com a sua filha estão inseridos no campo do fatum, porque se constituem como eventos que estão além de qualquer superação moral, e a este Tiestes admite que vai além

\footnotetext{
${ }^{21}$ Harsh, 1960, p. xxiv.

${ }^{22}$ Sobre o mito, apenas para citar alguns, ver Grimal (1992) e Soares (2004).

${ }^{23}$ Soares, 2004, p. 51. Tendo já sido tratado nas tragédias gregas, este mito serviu de tema para o desenvolvimento de várias tragédias na literatura latina, desde Énio com Tiestes, aos Atreus de Ácio e ao Tiestes de Vário. Séneca além de Agamemnon, escreve Thyestes e as Troades sob o mesmo mito, e desde o Renascimento até aos dias de hoje é ainda um mito que permite a criação de belas peças de teatro. ${ }^{24}$ Ferreira, 2011, p. 107.

${ }^{25}$ Os fantasmas em Séneca aparecem como monstra nas suas peças, sendo forças poderosas e não "peças decorativas", como considera Charles Whitmore (1915).

${ }^{26}$ Lohner in Sêneca, 2009, p. 162.
} 
da inelutabilidade do destino. Mais do que isso, incita o seu filho, Egisto, fruto dessa relação incestuosa, contra Agamémnon, em busca de vingança ${ }^{27}$ :

Thyestae Vmbra

Iam scelera prope sunt, iam dolus caedes cruor-

parantur epulae. Causa natalis tui,

Aegisthe, uenit. Quid pudor unltus grauat?

Quid dextra dubio trepida consilio labat?

Quid ipse temet consulis torques rogas

an deceat hoc te? Respice ad matrem: decet.

Espectro de Tiestes

Já os crimes estão perto, a fraude, a morte, o sangue:

apresta-se o festim. De tua nascença veio,

Egisto, a causa. O rosto teu, de que se peja?

Por que tua mão resvala trêmula e hesitante?

Por que é que te consultas, te afliges e indagas

se isso condiz contigo? Vê tua mãe: condiz. (v. 47-52) ${ }^{28}$

Apesar de estarmos a falar de um fantasma, mas que outrora fora um homem real, aproveitamos o tópico dos monstra em Séneca, e apresentamos a opinião de Staley, ${ }^{29}$ ao referir que Séneca decidiu fazer as suas tragédias monstruosas, porque, na epistemologia estoica, monstra constitui uma vívida imagem da realidade. Séneca entende que a enárgeia é um tipo que "põe ante os olhos o quanto de monstro tem uma pessoa que está furiosa com um membro humano". ${ }^{30}$ Ao contrário do que acontece em Virgílio, Séneca conota os seus monstra não como uma antítese do ser humano, mas como sinónimo dele, e apresentam-se como monstros na plena aceção da palavra. ${ }^{31}$

Assim, aparece-nos Clitemnestra, atingida pela dor, o que permite que descubra "uma nova identidade, dentro de outro mundo, esse de monstros", descoberta esta ligada a cenas de carnificina, quando o corpo do herói é mutilado, ensanguentado, sendo a ação trágica "centrada no corpo do herói, porque o corpo do herói é uma parte indissociável da de sua pessoa heroica". 32

No canto coral que se segue com o Coro das Argivas, são-nos apresentadas, aliás como acontece em todos os cantos corais, "as reflexões mais importantes sobre a efemeridade das coisas, a alternância de fatos bons e maus, a instabilidade do poder, a força do destino". ${ }^{33}$

\footnotetext{
${ }^{27}$ Germano, 2012, p. 2-3.

${ }^{28}$ Todas as traduções dos trechos de Agamémnon são de José Eduardo dos Santos Lohner (2009).

${ }^{29}$ Staley, 2010, p. 117.

${ }^{30}$ Séneca, De Ira 3.3.2 apud Staley, 2010, p. 80.

${ }^{31}$ Staley, 2010, p. 119-120.

${ }^{32}$ Dupont, 1995, p. 17-18 apud Carmo, 2009, p. 2.

${ }_{33}$ Cardoso, 2005, p. 170.
} 


\author{
Chorus \\ O regnorum magnis fallax \\ Fortuna bonis, in praecipiti \\ dubiosque locas nimis excelsos. \\ Nunquam placidam sceptra quietem \\ certumue sui tenuere diem: \\ alia ex aliis cura fatigat \\ uexatque animos nou tempestas. \\ Coro de Argivas \\ Ó Fortuna, enganosa para os reinos, \\ colocas, com teus magnos dons, no abismo \\ e na incerteza os que demais se elevam. \\ Nunca os cetros um palácio repouso \\ tiveram ou um dia sem ter susto: \\ a inquietude os fatiga, uma após outra, \\ e aflige os corações nova tormenta. (v. 57-63)
}

Neste âmbito verificamos, como refere Lohner, ${ }^{34}$ que este primeiro canto das mulheres argivas adverte sobre os infortúnios e a vulnerabilidade das posições elevadas, tendo utilizado Séneca um processo de amplificação em que são alternadas as referências aos males que os poderosos padecem, juntamente com imagens que aludem à ideia de reversão do destino. No entanto, apesar de se mostrar um tanto ou quanto distanciado dos eventos centrais do drama, o Coro faz comentários que apontam diretamente para a situação de Agamémnon: a perfídia e os crimes numa corte, que conduzem à ruína dos soberbos mandatários.

Desta forma, encontramos traçada a ideia do término da ataraxia, a tranquilidade da alma, que é cara aos estoicos, sobre aqueles que detém um estatuto social elevado e o poder, e que, perturbados pelos vícios da soberba e da ganância, são levados à queda e à constante desconfiança com aqueles que o rodeiam. Este estado de espírito leva a que fiquem impedidos de conseguirem trilhar o caminho para a felicidade, a eudaimonía, ${ }^{35}$ tal como acontece com Agamémnon:

\author{
Chorus \\ ...Quidquid in altum \\ Fortuna tulit, ruitura leuat. \\ Modicis rebus longius aeuum est: \\ felix mediae quisquis turbae \\ sorte quietus \\ aura stringit litora tuta \\ timidusque mari credere cumbam \\ remo terras propiore legit.
}

\footnotetext{
${ }^{34}$ Lohner in Sêneca, 2009, p. 164-165.

${ }^{35}$ Germano, 2012, p. 4.
} 
Coro de Argivas

... O que para o alto

A Fortuna levou há de arruiná-lo.

mais longa é a vida de hábitos modestos:

feliz quem é da multidão mediana,

em paz com a sua sorte,

margeia as praias sob uma aura estável

e ao mar temendo confiar o seu barco,

resvala a terra com o remo rente. (v. 100-107)

Segue-se Clitemnestra, no segundo ato da peça, que questiona seu animus, recurso próprio das tragédias antes de ser cometido um crime, revelando assim, uma certa inconstantia, uma desagregação do estado interno da personagem: Quid, segnis anime, tuta consilia expetis?, "Por que, alma fraca, anseias por conselho certo?" (v. 108). ${ }^{36}$

No diálogo com a Nutrix, expressa o seu ódio pelo rei, vislumbrando-se nas suas palavras, embebidas de dolor e furor, os crimes que cometerá, não só contra o marido, mas também contra Electra, sua filha. No v. 114, da frena et omnem prona nequitiam incita, "Larga as rédeas, e firme incita todo vício", estamos perante uma Clitemnestra que deixa de lado a virtude e entrega o seu espírito à sorte dos páthè, das paixões, deixando-se dominar pelo furor.

Séneca, segundo Tarrant,${ }^{37}$ gostava de escrever tragédias de forma que a sua audiência sentisse as consequências da paixão, o choque, ékplèxis, e a aversão, stupor, nas cenas mais efetivas, estimulando assim uma consciência moral e um crescimento, e desta forma conseguia que a sua audiência sentisse, já que este sentir é a propriedade natural do drama. ${ }^{38}$

Em Séneca os elementos trágicos operam numa contenda sobretudo interior, numa luta contra as paixões, até certo ponto num conflito direto com os poderes divinos, com os princípios morais universais, ou com a ordem inflexível do mundo. ${ }^{39}$

Mas a verdade é que no estoicismo o homem tem a liberdade de agir de formas diferentes perante as circunstancias que lhe surgem no caminho. Por isso, a Nutrix, perante este discurso, questiona-a sobre os tumido feroces impetus que traz na alma (v. 127), mas tenta, aparecendo como a voz da razão, demover Clitemnestra daquilo a que se propõe, e tenta fazer com que a sua ira se apazigue.
Nvtrix
Regina Danaum et inclitum Ledae genus,
quid tacita uersas quidue consilii impotens
tumido feroces impetus animo geris?
Licet ipsa sileas, totus in uultu est dolor.

\footnotetext{
36 Ver Larson, 1994, p. 151-152. Relativamente à situação de inconstantia, ver também a fala de Clitemnestra, v. 192, Accingere, anime, e de Egisto v. 228, Quid terga uertis, anime?

${ }^{37}$ Tarrant, 1985 , p. 24-25.

${ }^{38}$ Staley, 2010, p. 81.

${ }^{39}$ Segal, 2008, p. 139.
} 
Proin quidquid est, da tempus ac spatium tibi:
quod ratio non quit, saepe sanauit mora.

Ama

Raça ilustre de Leda, rainha dos dânaos, o que engendras calada ou, carente de senso, que ferozes impulsos trazes na alma túrgida? Inda que cales, toda a dor está em teu rosto. Assim, seja o que for, cede-te um tempo e um prazo. O que a razão não pode, a espera às vezes cura. (v. 125-130)

Nesse diálogo com a Nutrix, em que são utilizadas a esticomitia ${ }^{40}$ e as sententiae $e^{41}$ (v. 145-154), Clitemnestra revela os sentimentos que o furor lhe traz, desde a dor que o sacrifício da sua filha Ifigénia, pela mão do seu marido, lhe causa, e o ciúme que tem desse mesmo devido às suas conquistas femininas. Mas mesmo dominada pelo furor, Clitemnestra pode escolher entre cometer o crime ou não.

Para Séneca, a raiva justapondo-se com os tristia e o timoratinge o conhecimento, ainda que indirecto, da tristeza e do medo aristotélicos como características responsáveis provocadas pela tragédia. ${ }^{42}$ É esta tristeza e medo que encontramos nas palavras de Clitemnestra, aquela mulher a quem seu "ser chamas consomem e [o seu] coração./ Mesclado à dor, o medo crava-[lhe] grilhões" (v. 132-133). ${ }^{43}$

Clitemnestra é levada pela ira, pela dor, é acometida pela falta de esperança, deixa-se levar, tal como a um barco: quocumque me ira, quo dolor, quo spes feret, / huc ire pergam; fuctibus dedimus ratem (v. 142-144). Mas mesmo esta raiva, segundo Graver, é-nos apresentada por Séneca como um ato consciente e que está debaixo do nosso controlo. ${ }^{44}$

Em primeira instância, encontramos no agon da Nutrix e de Clitemnestra, e comparando-o igualmente com aquele que se dará entre a rainha e Egisto, a determinação com que a rainha decide vingar-se do marido. ${ }^{45}$

No entanto, nos versos 239-43, 263-7, 273-4, 284, 286, encontramos uma Clitemnestra que tem expectativas relativamente a uma possível reconciliação com o seu marido e sente que o pode perdoar das ofensas praticadas. No entanto, tais esperanças sairão goradas. Clitemnestra acusa mesmo Egisto de ser resultado de um incesto e de não ter coragem (v. 239, 295-301), mas a verdade é que o comportamento do chefe Atrida não permite que haja lugar para uma reconciliação com a esposa. Mas, mais do que uma questão

\footnotetext{
${ }^{40}$ Esticomitia é um recurso utilizado que consiste num diálogo em que os versos alternados encerram em si um pensamento completo.

${ }^{41}$ Sententiae muito utilizadas por Séneca nas suas peças (não fosse ele um filósofo) consistem em enunciados que sintetizam uma norma de conduta.

${ }^{42}$ Brad Inwood, 1993, p. 178 apud Staley, 2010, p. 74.

${ }^{43}$ flammae medullas et cor exurunt meum;/ mixtus dolori subditit stimulus timor.

${ }^{44}$ Graver, 2007 apud Staley, 2010, p. 74.

${ }^{45}$ Ferreira, 2011, p. 116.
} 
de sentimentos, o que se torna mais importante prende-se com a questão da perpetuação futura das desfeitas, desonras e traições à Tindarida, que poderão culminar mesmo no repúdio (224-259, 268-272, 275-283, 285). Mais uma vez a dimensão hereditária do crime também é salientada pelo filho-neto de Tiestes (226-233, 292-3, 294). ${ }^{46}$

Segundo Ferreira (2011, p.108), "Egisto e Clitemnestra estão destinados a recriar o passado: o primeiro não perde de vista o destino que marcou o seu nascimento $(48,226 s s$, 223); a morte de Ifigénia e as ligações de Agamémnon com as cativas troianas e, em particular, com Cassandra estão no espírito de Clitemnestra (162ss). Esta não tem mores, ius, decus, pietas, fides...pudor (112ss), mas Agamémnon já tinha perdido tais virtudes no passado (158ss, 164ss)."

As protagonistas de Séneca lutam mais com elas próprias do que com as leis do universo ou com as condições fundamentais da vida e da sociedade. Clitemnestra atrai o mal para si própria, tal como uma Medeia, uma Fedra, um Tiestes ou um Hércules, exemplificando a qualidade da genuína tragédia: eles sofrem a culpa, tomam a responsabilidade pela sua derrota, pelos seus próprios descontrolos emocionais, e sofrem física e moralmente as consequências das suas ações. ${ }^{47}$ Os heróis trágicos de Séneca tornam-se alienados dos aspetos da sua própria humanidade, da racionalização moderada do desejo, do ódio, do amor, do medo, da esperança, do desespero e da culpa. ${ }^{48}$

A confusão emocional continua no terceiro ato com o relato do mensageiro Euríbates, que depois da intervenção do segundo Coro (v. 310-391), anuncia a Clitemnestra o regresso de Agamémnon e narra a tempestade que fez com que muitos dos barcos da armada grega se afundassem. A mescla que atravessa a origem da dinastia dos Pelópidas como um nefas inadmissível, seguindo-se a trama do crime sacrílego por parte da rainha, atualiza-se numa desordem cósmica que se apresenta no relato de Euríbates. O mensageiro nas suas palavras iniciais inscreve o regresso de Agamémnon num oximoro em que conjuga as palavras laetum e infaustum: ${ }^{49}$

\author{
Eurybates \\ Acerba fatu poscis, infaustum iubes \\ miscere laeto nuntium. Refugit loqui \\ mens aegra tantis atque inhorrescit malis. \\ Euríbates \\ É amargo narrar. Mandas unir a funesta \\ notícia a uma alegre. Furta-se a falar \\ minha alma aflita, e sente horror de tantos males. (v. 416-418)
}

Se, por um lado, vemos no relato a dissolução dos limites da natureza durante a tempestade (v. 407, v. 473-474, v. 490), por outro, essa mesma violência em que é descrita a

\footnotetext{
${ }^{46}$ Ferreira, 2011, p. 90.

${ }^{47}$ Segal, 2008, p. 140.

${ }^{48}$ Segal, 2008, p. 140.

${ }^{49}$ Tola, 2009, p. 6-7.
} 
natureza (v. 450, v. 469) é-nos apresentada, em primeira instância, através da ira que domina Clitemnestra nos versos 126-127.

Pode-se dizer que o tema do 'retorno' atravessa a peça, manifestando-se sobretudo em duas imagens: o regresso do rei à sua pátria, no plano temático, e o retorno a um estado anterior no plano simbólico dos acontecimentos trágicos. ${ }^{50}$ Se por um lado temos a figura de Tiestes que surge no princípio do drama, com o seu regresso do mundo dos mortos, e com a sua representatividade relativamente à história decorrente do banquete ímpio e o incesto com a sua filha, temos, por outro, a figura de Agamémnon, que, com o seu regresso, se torna como aquele que irá desencadear os vários acontecimentos trágicos, que se antecipam à própria personagem. ${ }^{51}$

Tendo em conta as referências ao longo da peça, nos discursos das personagens, não se estranha quando se associa a morte do chefe Atrida a uma vingança pela morte de Príamo e pela destruição de Troia (v. 791-5, 869ss), verificável nas antilabaí do diálogo entre este e Cassandra, e onde são mencionados os seguintes factos: a morte do Atrida foi feita com base numa traição e na perfídia (v. 612-26, 732, 887ss, 1009), decorrente num festim (v. 311ss, 644ss, 780, 791, 875ss), motivada, em parte, pelo adultério, finalizando com um presente fatal (v. 628, 1009). No discurso de Euríbates também encontramos a referência da morte de Príamo junto ao altar de Júpiter Hecateu (v. 448). ${ }^{52}$

Ao ir ao encontro da história da guerra de Troia, em que Agamémnon pertence ao exército dos vencedores, há, ao longo da peça, um discurso que ronda os conceitos de vencedor e vencido. Agamémnon é um vencedor aos olhos da Nutrix (... uictor uenit) Asiae ferocis, ultor Europae; trahit/ captiua Pergama et diu nictos Phrygas, v. 204-206), aos de Euríbates (tandem ad penates uictor Agamemnon suos, v. 396ª), do Coro (uictrice lauru cinctus Agamemnon adit, v. 79) e aos seus próprios olhos (Victor timere quid potest?, v. 798).

No entanto, deparamo-nos com uma certa ambiguidade no que respeita a esta dualidade entre vencedor e vencido, não só nas palavras do próprio Euríbates, nos versos 412 413 (remeatque victo similis, exiguas trahens/ lacerasque nictor classe de tanta rates), como nas palavras de Clitemnestra, que considera o chefe Atrida um vencido (sine hoste victus marcet..., v. 183).

Criando um paralelismo da ação atual com a do passado, nomeadamente com a queda de Troia, a visão profética de Cassandra assinala a vingança que implica um regresso ao estado anterior dos troianos e da sua família: ${ }^{53}$ agora os vencidos tornam-se vencedores (uicimus

\footnotetext{
${ }^{50}$ Tola, 2009, p. 9.

51 Tola, 2009, p. 9.

${ }^{52}$ Ver Ferreira 2011, p. 108.

${ }^{53} \mathrm{O}$ coro constituído por mulheres troianas, que encerra o terceiro ato e o diálogo com Cassandra mais adiante, aborda a questão da condição de prisioneiras a que foram submetidas, referindo também uma questão cara ao estoicismo que é a da "morte como único meio de liberação disponível aos homens diante da ação opressora do destino" (Lohner, Sêneca, 2009, p. 197): Heu quam dulce malum mortalibus additum/ uitae dirus amor, cum pateat malis/ effugium et miseros libera mors nocet/ portus aeterna placidus quiete. "Ah, quão doce esse mal lançado aos mortais, / da vida o acerbo amor, embora se abra aos males/ um refúgio e aos desditosos chame a morte redentora,/ plácido porto de eterno repouso” (v. 589-592).
} 
uicti Phryges, v. 869), Troia ressurge (resurgis, Troia, v. 870), e Agamémnon, caracterizado até aí como uictor, torna-se uictus, aquele que venceu a tempestade será vencido pelas tormentas que agitam a sua própria casa. Desta forma anulam-se as fronteiras temporais dos acontecimentos para focalizar-se o carácter cíclico da história, ou seja, a ideia do presente como produto e representação dos antigos atos. ${ }^{54}$

Neste diálogo entre Agamémnon e Cassandra, o rei continua a não compreender que a sua situação se encontra precária e que a história do seu passado regressará, fazendo dele agora a sua vítima, verificando que o scelus dos Pelópidas reveste-se das mesmas formas, encontradas em Thyestes: o engano, o banquete e o sacrifício, em que Agamémnon é a vítima que é imolada (v. 43, v. 219), por sua esposa Clitemnestra que desfecha o golpe que será fatal (v. 897-900). ${ }^{55}$

Assim, ao contrário do que acontece na obra de Ésquilo, em que o chefe Atrida é morto durante o banho (v. 1107-11; v. 1126-9), Séneca, aproximando esta peça das duas outras que tratam o drama do Atridas, faz com que a sua morte se dê durante um banquete, como se se tratasse de um verdadeiro sacrifício, anunciado primeiramente pelo fantasma de Tiestes e mais tarde pela Ama:

\section{Thyestae Vmbra \\ rex ille regum, ductor Agamemnon ducum \\ adest, daturus coningi ingulum suae. \\ Iam iam natabit sanguine alterno domus. \\ Enses secures tela, diuisum grani \\ ictu bipennis regium uideo caput.}

Tiestes

rei dos reis, Agamêmnon, chefe dentre os chefes, (v. 39)

... aqui está, para dar à sua esposa o pescoço.

Logo imerso o palácio estará noutro sangue:

armas, secures, lanças, decepada ao duro

ataque da bipene, vejo a régia fronte. (v. 43-46)

Nutrix

... bunc domi reducem paras

mactare et aras caede maculare impia.

Ama

... a ele, que retorna,

vais imolar, manchando o altar com ímpia morte. (v. 218-219)

\footnotetext{
${ }^{54}$ Tola, 2009, p. 10.

${ }^{55}$ Soares, 2004 , p. 53-54.
} 
O scelus de Clitemnestra apresenta-se como a repetição do crime hereditário que caracteriza a casa dos Atridas, na "casa que com crimes sempre vence crimes", scelera semper sceleribus vincens domus (v. 169).

Nos dramas senequianos encontramos difundida a questão da identidade do destino que está sempre já escrito, predeterminado pelo nome e pela história familiar. Egisto invoca o seu próprio nome para se auto persuadir de que não tem outra escolha senão emergir ele próprio numa história destrutiva de vingança: ${ }^{56}$

\section{Aegisthus \\ ...Crede pernicem tibi \\ et dira saenos fata moliri deos:}

oppone cunctis wile suppliciis caput

ferrumque et ignes pectore aduerso excipe,

Aegisthe: no est poena sic nato mori.

Egisto

...Crê: destruição e um terrível

destino é o que os severos deuses te preparam.

Opõe tua vil pessoa a todos os suplícios

e rebate, com peito hostil, o ferro e as chamas,

Egisto: a quem assim nasceu não dói morrer. (v. 229-233)

O ponto central do drama assenta no assassinato do rei por Clitemnestra e Egisto, num ato sacrílego que acaba mesmo por se apresentar como um anti-sacrifício: qualisque ad aras colla taurorum popa/ designat oculis antequam ferro petat, "qual popa que, no altar, as cernelhas dos touros/ aponta com o olhar antes que vibre o ferro" (v. 898-9).

Mais do que a aparência de um ritual de sacrifício, outra imagem surge aos olhos dos espectadores pelas palavras de Cassandra, quando nos dá conta da morte do chefe Atrida (Habet, peractum est). ${ }^{57}$ Clitemnestra desferiu o golpe fatal, tal como um gladiador o faz na arena, e perante esta expressão, assim como toda a descrição que envolve esta ímpia morte, faz lembrar ao espectador os grandiosos espetáculos nas arenas de Roma, ${ }^{58}$ transpondo-o da peça para a arena, transformando-o de mero espectador a testemunha: ${ }^{59}$

\footnotetext{
${ }^{56}$ Fitch e McElduff, 2008, p. 166.

57 “Eis! Consumado está!” (v. 901).

${ }^{58}$ É interessante notar que Séneca expressa uma certa repulsa no que respeita à luta de gladiadores e a outros espetáculos de selvajaria nos seus escritos filosóficos. No entanto, não só utiliza, nas suas tragédias, alusões que nos transportam para este tipo de entretenimento tão em voga entre os romanos, como, ao analisarmos essas mesmas peças, o sofrimento humano e uma violência sanguinária são tópoi recorrentes, traduzindo-se assim num "enjoyable disgusting”, como o denomina Hesk (2007).

${ }^{59}$ Erasmo, 2004, p. 128-129.
} 
sic huc et illuc impiam librat manum.

Habet, peractum est. Pendet exigua male

caput amputatum parte et hinc trunco cruor

exundat, illinc ora cum fremitu iacent.

Nondum recedunt: ille iam examinem petit

laceratque corpus, illa fodientem adiunat.

ela, a mão ímpia, assim balança aqui e ali.

Eis! Consumado está! De estreita parte pende,

mal amputada, sua cabeça e o sangue jorra

do tronco; a face, com um frémito, desaba.

E ainda não recuam: ataca, ele, o corpo

sem vida e o lacera; ela, ajuda o algoz. (v. 900-905)

Considerando que o espectador acaba por se tornar uma testemunha no processo dramático, é interessante notar que Erasmo considera que a tragédia de Séneca pode ser encarada como uma metatragédia, e o espectador assume essa mesma posição de testemunha quando "the theatricalized stage actions of actors compete with their own perception of the world outside the theatre, making the recognition of dramatic allusion on the stage and the interpretation of dramatic allusion off the stage difficult". ${ }^{60}$

Neste último ato, em que nos é descrito o assassinato de Agamémnon por Cassandra, através de uma visão profética, vemos que o rei não consegue fugir ao seu fatum. Também ela tem o seu destino traçado e é condenada à morte por Clitemnestra, mas não morrerá sem lhe dizer e a Egisto que Veniet et uobis furor, “Também a vós virá uma fúria” (v. 1012), fúria esta vinda de Orestes ao querer vingar-se. Termina, assim, a peça sem catarse, numa evocação do furor, que não se justifica nos estoicos, ${ }^{61}$ tendo em conta que o estoicismo apresenta-se com uma doutrina que pretende ensinar que a felicidade ideal só pode ser alcançada quando o homem aprende a viver de acordo com a natureza e aceitando os acontecimentos e a serenidade da vida. ${ }^{62}$

\section{CONCLUSÃo}

Séneca apresenta em Agamémnon as consequências que o amor trágico pode trazer, sem nunca esquecer, e que de facto se torna o principal, a associação de Agamémnon a uma culpa pessoal e hereditária, iniciando-se com ele um processo de expiação. Clitemnestra surge como a mulher que pretende assassinar o marido, movida não só pela paixão que nutre por Egisto, mas sobretudo pela lembrança do sacrifício da sua filha Ifigénia em Áulide, e tomada pelo ciúme que tem de Agamémnon, devido às suas conquistas amorosas. É um crime marcado pela violência, pela crueldade, mas surge como algo que pode ser evitado.

\footnotetext{
${ }^{60}$ Erasmo, 2004, p. 122.

${ }^{61}$ Soares, 1998, p. 61

${ }^{62}$ Cardoso, 2005.
} 
Apesar das consequências que dele pode advir, ele é consumado, a catástrofe dá-se. Desde o início da peça, com a Vmbra de Tiestes, é anunciado o ciclo de crimes que decorrerá na ação seguinte, ${ }^{63} \mathrm{o}$ fim do chefe Atrida.

O assassínio de Agamémnon apresenta, assim, três dimensões diferentes: a ancestral e familiar, vingando o festim macabro de Tiestes; uma civilizacional, de desagravo de Príamo e a vitória dos Aqueus sobre os Troianos; e uma pessoal e familiar, devido ao sacrifício de Ifigénia. ${ }^{64}$

Agamémnon, “o herói homérico, que serviu de paradigma ao ideal do príncipe, "pastor dos povos", ${ }^{65}$ apresenta-se como uma personagem marcada "pela alternância de qualidades, tendendo para o bem ou para o mal, mas condenado a cair, em momento fatal, na perversão do poder e a ser castigado", um herói humanizado. ${ }^{66}$ Afigurando-se primeiramente como um bom rei (tanto pela Nutrix, por Euríbates, Electra e Cassandra), Agamémnon deixar-se-á cair na býbris, durante o festim de regresso: Victor timere quid potest? "Quem vence, há de temer o quê?" (v. 799).

O castigo do chefe Atrida, além de ser uma expiação pelo passado familiar e pela morte de Ifigénia, é, sobretudo, um castigo que tem a ver com a degeneração da monarquia em tirania, do seu excesso de confiança e de orgulho, mas apresenta também aquele que tem consciência da sua culpa e faltas, e reflete e aprende com elas, ilustrando, assim, a máxima que enunciará, ou seja, os perigos inevitáveis da condição real. ${ }^{67}$ Tal como aconteceu com Tiestes, na obra homónima, Agamémnon parece iniciar o percurso do sapiens estoico, um ser em busca de aperfeiçoamento, mas que, ao mesmo tempo que tenta lutar, fá-lo com pouca convicção, o que o leva a ceder ao furor regni, negando o ideal de sapientia, e expondo-se às consequências desse mesmo ideal, ${ }^{68}$ como já antevemos nas palavras de Cassandra.

$\mathrm{Na}$ mentalidade estoica, e abarcando esta questão em Agamémnon, o homem ideal, o sábio, para não ser dominado pelas paixões, deve refletir sobre os seus modos de ação, buscando sempre os valores que são realmente fundamentais para o ser humano. ${ }^{69}$

\section{REFERÊNCIAS}

BOYLE, Anthony J. An introduction to roman tragedy. London and New York: Routlledge, 2006.

CARDOSO, Zelia de Almeida. O tratamento das paixões nas tragédias de Sêneca. Letras Clássicas, n. 3, 1999, p. 129-145. Disponível em: < http://www.revistas.usp.br/letrasclassicas / article/view/73759/77425>.

\footnotetext{
${ }^{63}$ Boyle, 2006. p. 199.

${ }^{64}$ Ferreira, 2011, p. 109.

${ }^{65}$ Soares, 2004, p. 56.

${ }^{66}$ Oliveira, 1999, p. 50, 62.

${ }^{67}$ Oliveira, 1999, p. 64.

${ }^{68}$ Soares, 2004, p. 66.

${ }^{69}$ Pirateli, 2008, p. 263.
} 
CARDOSO, Zelia de Almeida. Estudos sobre as tragédias de Sêneca. São Paulo: Alameda, 2005.

CARDOSO, Zelia de Almeida. A função didáctica das tragédias de Sêneca. Paideuma, Grupo de Estudos Clássicos e Medievais da Faculdade de Educação da Universidade de São Paulo, 2005. Disponível em: <http://www.paideuma.net/zelia4.doc>.

CARMO, Tereza Pereira do. O banquete monstruoso. Anais de SILEI, v. 1, 2009.

DUPONT, Florence. Les monstres de Sénèque. Paris: Belin, 1995.

ERASMO, Mario. Roman tragedy: theatre to theatricality. Austin: University of Texas Press, 2004.

ÉSQUILO. Oresteia: Agamémnon, Coéforas, Euménides. Trad. Manuel Oliveira Pulquério. Lisboa: Edições 70, 1992.

FERREIRA, Paulo Sérgio M. Séneca em cena: enquadramento na tradição dramática grecolatina. Lisboa: Fundação Calouste Gulbenkian e Fundação para a Ciência e para a Tecnologia, 2011.

FITCH, John G.; MCELDUFF, Siobhan. Construction of the self in Senecan drama. In: . (ed.). Oxford readings in Classical Studies: Seneca. Oxford: Oxford University Press, 2008.

GERMANO, Ricardo. O estoicismo e as paixões no Agamêmnon de Sêneca. Revista Desenredos, ano IV, n. 14, jul./set., 2012.

GRAF, Fritz. Religion and drama. In: McDONALD; Walton; J. MICHAEL (ed.). Greek and Roman tragedy. Cambridge: Cambridge University Press, 2007.

GRAVER, Margaret. Stoicism and Emotion. Chicago: University of Chicago Press, 2007.

GRIMAL, Pierre. Dicionário de mitologia grega e romana. Lisboa: Difel, 1992.

GRIMAL, Pierre. L'image du pouvoir royal dans les tragédies de Sénèque. Dramaturgie et actualité du théâtre antique. Actes du Colloque Internacional de Toulouse, 17-19 Oct., Pallas 38, 1992.

HARSH, Philip Whaley. An anthology of Roman drama. New York: Holt, Rinehart and Winston, 1960.

HESK, Jon. The social-political dimension of ancient tragedy. In: McDONALD; Walton; MICHAEL, J. (ed.). Greek and Roman tragedy. Cambridge: Cambridge University Press, 2007.

LARSON, Victoria Tietze. The role of description in Senecan tragedy. Frankfurt am Main; Belin; Bern; New York; Paris; Wien: Peter Lang, 1994.

MONTAGNER, Airto Ceolin. O poder da palavra na tragédia latina. IV Congresso de Letras da Universidade do Estado do Rio de Janeiro. Anais do IC CLUERJ-SG, v. 1, 2007. Disponível em: <http://www.filologia.org.br/cluerj-sg/anais/iv/completos/mesas/M8/Airto\%20Ceolin\% 20Montagner.pdf $>$.

MOST, Glenn. W. Generating Genres: The Idea of the Tragic. In: DEPEW, Mary; OBBINK, Dirk (ed.). Matrices of Genre: Authors, Canons, and Society. Cambridge: Harvard University Press, 2000. 
OLIVEIRA, Francisco de. A imagem do poder na tragédia de Séneca. Humanitas, v. 51, 1999. PARATORE, Ettore. História da Literatura Latina. Lisboa: Fundação Calouste Gulbenkian, 1983.

PIRATELI, Marcelo Augusto. As tragédias de Sêneca e o seu aspecto educativo. Revista Cesumar, Ciência Humanas e Sociais Aplicadas, v. 13, n. 2, p. 257-267, jul./dez. 2008. Disponível em: <http://www.cesumar.br/pesquisa/periodicos/index.php/revcesumar/article / view/644/631>.

ROCHA PEREIRA, Maria Helena da. História da Cultura Clássica. v. 2: Cultura Romana. 2. ed. Lisboa: Fundação Calouste Gulbenkian, 1989.

SEGAL, Charles. Boundary violation in Senecan tragedy. In: FITCH, John G. (ed.). Oxford readings in Classical Studies: Seneca. Oxford: Oxford University Press, 2008.

SEGURADO E CAMPOS, José António. Séneca, Tiestes. Lisboa: Verbo, 1996.

SÊNECA. Agamêmnon. Trad., introd., posfácio e notas de José Eduardo dos Santos Lohner. São Paulo: Editora Globo, 2009.

SOARES, Nair de Castro. Martírio e sacrifício voluntário na tragédia humanista e no mito inesiano: em António Ferreira e Eugénio de Castro. Humanitas, v. 48, 1996.

SOARES, Nair de Castro. Literatura Latina: teatro, sátira, epigrama e romance: Guia de Estudo. Antologia. 2. ed. Coimbra: Universidade de Coimbra, 1998.

SOARES, Nair de Castro. O drama dos Atridas: a tragédia Thyestes de Séneca. Ágora Estudos Clássicos em Debate, n. 6, 2004.

STALEY, Gregory A. Seneca and the ideia of tragedy. Oxford: Oxford University Press, 2010.

TARRANT, R. J. Seneca Agamemnon. Cambrige; London; New York; Melbourne: Cambridge University Press, 1976.

TOLA, Eleonora. Una lectura del Agamemnon de Séneca: nefas trágico e imaginário poético. Auster, n. 14, En Memoria Académica, 2009. Disponível em: < http:/ /www.memoria.fahce.unlp. edu.ar/art_revistas/pr.4004/pr.4004.pdf $>$.

WHITMORE, Charles E. The supernatural in tragedy. Cambridge: Harvard University Press, 1915.

WILES, David. Aristotle's Poetics and ancient dramatic theory. In: McDONALD; Walton, MICHAEL, J. (ed.). Greek and Roman tragedy. Cambridge: Cambridge University Press, 2007.

WISEMAN, T. P. Roman legend and oral tradition. Journal of Roman Studies, v. 79, 1989.

Recebido em: 24 de fevereiro de 2015 Aprovado em: 19 de julho de 2016 